\title{
Share buy-backs for a selection of JSE listed companies: An exploratory study
}

\author{
P.G. Bester, N. Wesson* and W.D. Hamman \\ University of Stellenbosch Business School, \\ PO Box 610, Bellville 7535, Republic of South Africa \\ nwesson@telkomsa.net
}

Received September 2010

\begin{abstract}
This study undertook to derive share repurchase trends from a small sample of JSE-listed companies over the nine years, $1999-2008$. The study also draws attention to the particular obstacles to be overcome when conducting research into the unique South African share repurchases environment.

The study finds that 33 companies made 71 repurchase announcements (47 general and 24 specific) via the Securities Exchange News Service (SENS) over the period July 1999 until financial year-end in 2008. On average, 59,0\% of the total number of shares (and 49,3\% of the total value) repurchased under a general authority is not included in the 3\% SENS announcements. General share repurchases represent $47,9 \%$ of total repurchases in volume (and $60,5 \%$ in terms of value). The total number of shares repurchased (excluding share trust purchases) by the 33 companies shows that 56,8\% were repurchased by subsidiaries and $17,1 \%$ were subsequent repurchases by companies from subsidiaries. (In value, these repurchases represent $53,7 \%$ and $17,2 \%$, respectively.)
\end{abstract}

This study therefore concludes that research based on only the 3\% SENS announcements of general share buy-backs results in significant understating of actual total share buy-back activities, and that the South African share repurchase environment presents unique challenges. The main obstacle for future South African research in this field however is the lack of comprehensive and accurate share repurchase data as supplied by South African financial data sources.

This material is based upon work supported financially by the National Research Foundation. Any opinion, findings and conclusions or recommendations expressed in this material are those of the authors and therefore the NRF does not accept any liability in regard thereto.

*To whom all correspondence should be addressed.

\section{Introduction}

South African companies have been allowed by law (Act 37 of 1999) to repurchase their own shares since 1 July 1999. Previous South African studies on share repurchase behaviour were conducted by Daly (2002) and Bhana (2007) and covered the periods July 1999 to September 2001 and October 2000 to March 2003 respectively. Both Daly and Bhana incorporated only announced general (or open market) share buy-backs in their studies and based their research methods on comparative studies performed on American companies. Apart from the fact that research on share buy-backs needs to be updated to include all periods, from 1999 till 2008, it is necessary to ascertain whether studies incorporating only general share buy-backs are comprehensive, and also if comparative overseas studies can be applied pari passu in the South African share repurchase environment.

\section{Research problem and objectives}

Although share repurchasing by South African companies has been legal for the past nine years and despite widespread interest in this subject, local research on share repurchases has been limited. While extensive research on share repurchases in the United States of America (USA) has been done using databases like Standard and Poor's Compustat financial database, researchers attempting to extend this research to the South African environment have been confronted with a lack of comprehensive share repurchase data.

This study aims to update the trends in share repurchase activities by South African companies listed on the JSE Limited (JSE) over the past nine years in order to establish a framework for compiling a database for representative research. This study draws attention to the particular obstacles to be overcome when conducting research into the unique South African share repurchases environment.

In particular, this study investigates the relationship between the two methods of repurchasing shares that are available to South African companies, namely repurchases under general authority (general buy-backs) and repurchases under specific authority (specific buy-backs). Furthermore, it is evident that for general buy-backs the actual total shares 
repurchased differs from the repurchases that were announced, and the aim is therefore also to quantify the relationship between general buy-backs that were announced (via the Securities News Agency (SENS)) and actual total general buy-backs.

South African financial data sources (i.e. Reuters, McGregor BFA, and I-Net Bridge) were consulted in order to obtain share repurchase data, but these agencies were unable to provide the required data for the full period of nine years on a consistent basis. It is only for the most recent periods that certain information is available (e.g. McGregor BFA includes a line item for consolidated trusts for the past two years, for treasury shares for the past four years and for number of group shares for the past nine years). A verification process confirmed that the data are not always accurate (e.g. in respect of treasury shares and number of group shares) and that certain data are not supplied at all (e.g. number of company shares).

Owing to this lack of comprehensive and accurate data on share repurchases for companies listed on the JSE, this study undertook to derive the repurchase trends from a small sample of companies rather than trying to prove certain relationships between the repurchase methods for a statistically significant sample. In the process, this research hopes to contribute to the establishment of a comprehensive database that will facilitate further analytical research.

The following areas are excluded from this study and will be considered for research in future studies:

- The short- and long-term market reaction to share repurchases, including buy-and-hold simulation. (Buyand-hold simulation entails a comparison between share prices on separate dates: the repurchase date and a date in each of the four years subsequent to the repurchase. Abnormal returns are then calculated to ascertain the market's long-term reaction to the share buy-back.)

- Economic reasons for share repurchases, including, among others, net asset value per share compared to share price, to establish over- and under-priced companies.

- The methods of financing obtained by the repurchasing entities.

\section{The South African share repurchase environment}

Prior to 1 July 1999, South African companies were not allowed to repurchase their own shares. The Companies Act, Act 61 of 1973 (RSA, 1973), was amended through the Companies Amendment Act, Act 37 of 1999 (RSA, 1999), to make provision for companies to acquire their own shares. The relevant sections 85 to 90 of the Amendment Act impose various restrictive regulations on share repurchase activities, mainly to ensure that liquidity and solvency provisions will not be compromised by the repurchase activities.
In South Africa there are two share repurchase methods, general and specific (which can be split between pro rata offers and specific offers), available to companies. In other countries there are essentially four methods, namely: a fixed price tender offer, a Dutch auction tender offer, the open market share repurchase programme and a private offer (Daly, 2002: 5, 7). A South African repurchase under general authority is equivalent in style to that of an American open market share repurchase (Daly, 2002: 13). This share repurchase method is by far the most common method of repurchase in the USA, with over $90 \%$ of the dollar value of all repurchases between 1985 and 1993, as well as between 1984 and 2000, completed through the open market (Ikenberry, Lakonishok \& Vermaelen, 1995: 182; Grullon \& Michaely, 2002: 1 651). From 1996 untill 2004 open market purchase programmes account for $88 \%$ of all announced US repurchase programmes and the announced value thereof is over $93 \%$ of the total value of repurchase programmes (Banyi, Dyl \& Kahle, 2008: 460). In 1997 open market repurchases amounted to between $90 \%$ and $95 \%$ of share repurchases in Europe (Fairchild \& Zhang, 2005). A South African specific offer is analogous to a private offer, while the pro rata offer is equivalent in style to that of a form of an American fixed price tender offer (i.e. a pro rata offer) (Daly, 2002: 13).

The Companies Act requires a special resolution to approve the repurchase of shares under general and specific authority [Section 85(1)] and states that approval under general authority will only be valid until the next general meeting [Section 85(3)]. It also states that shares acquired by the company must be cancelled as issued share capital (and their status returned to that of authorised shares) [Section 85(8)]. The Act further provides that subsidiaries may purchase up to a maximum of $10 \%$, in total, of the issued shares of its holding company, but that these shares acquired by subsidiaries shall not be cancelled as issued shares [Section 89].

Additional requirements and provisions for share repurchases by listed companies are imposed by the Listing Requirements of the JSE (JSE, 2007). The Listing Requirements applicable to share repurchases under general authority (open market repurchase) include the following:

- The valid period of the general authority is limited until the next general meeting or for 15 months from the date of the resolution, whichever period is shorter [Section 5.67(h)];

- Shares may not be repurchased at a price higher than $10 \%$ above the weighted average market price of the preceding five business days [Section 5.72(d)]; and

- The maximum number of shares that can be repurchased under general authority by the company in any financial year is $20 \%$ in aggregate of the company's issued share capital of that class [Section 5.68].

(These requirements were amended in 2000 and 2003. Previously the Listing Requirements stated that the maximum number of shares that can be repurchased by the 
company in any financial year is $20 \%$ in aggregate of the company's issued share capital of that class, provided that open market repurchases do not exceed $10 \%$ of the shares, and that shares may not be repurchased at a price higher than $5 \%$ above the weighted average market price of the preceding five business days.)

It is further required that the company must report general repurchases through SENS once it has cumulatively acquired $3 \%$ of its initial number of issued shares (of that class, as at the date of the resolution) and each $3 \%$ thereafter. (SENS is the official electronic forum through which JSE-listed companies disseminate related information) [Section 11.27].

The Listing Requirements applicable to share repurchases under specific authority state that specific repurchases include a pro rata offer (being an offer to all securities holders pro rata to their existing holdings) and a specific offer (being an offer from securities holders specifically named) [Section 5.69]. An announcement needs to be made via SENS immediately after the terms of the repurchase have been agreed on and should state that a circular will be dispatched to all shareholders [Section 11.25] . Subsequent to the announcement, the company must pursue the proposal, unless the JSE permits the company not to do so [Section 5.69 $(\mathrm{g})]$.

In South Africa the shares repurchased by subsidiaries and other entities in the group represent treasury shares and need to be deducted from equity in the annual report of the holding company (SAICA, 2007b: IAS 32) (i.e. the consolidation principle). Shares repurchased by share incentive schemes are therefore analogous to shares repurchased by subsidiaries from an accounting perspective. Although share trust repurchases are not explicitly included in the sections of the Companies Act or Listing Requirements dealing with share repurchases, their effect needs to be acknowledged when researching share repurchase activities in South Africa. While the consolidation of subsidiary accounts has been standard practice, uncertainty has existed regarding the accounting treatment of share trusts prior to 2004. In February 2004 the JSE announced that all listed companies, for annual periods ending on or after 31 March 2004, were required to consolidate their share trusts (Wainer, 2004: 12; SAICA, 2004). Despite many companies not consolidating their share trusts prior to 2004, it was contended that the application of the principles of the accounting standard, IAS 27 Consolidated and separate financial statements (SAICA, 2007a), should generally lead to the consolidation of share trusts (Wainer, 2004).

Countries such as England (UK), Canada and Australia only allow share repurchases of own shares by the holding company and disallow share repurchases of holding companies' shares by subsidiaries and share trusts (Bhana, 2006: 241, 249). USA subsidiaries may acquire shares in the holding company, but restrictions are imposed (as an antiavoidance measure) on a holding company using a subsidiary company to hold and resell treasury shares on its behalf (Cassim, 2003: 148). Countries either require shares repurchased to be cancelled from issued and authorised share capital (e.g. Australia), shares repurchased to be cancelled only from issued share capital (e.g. Canada) or shares repurchased to remain as issued shares of the company, subject to the resale or cancellation thereof by the company (e.g. UK and the USA) (Cassim, 2003: 144, 145, 151). The resale of repurchased shares may then, for example, be made to beneficiaries of share incentive schemes (which makes the need for the creation of a separate share trust irrelevant) (Cassim, 2003: 147).

Most exchanges require disclosures immediately after repurchases have been implemented - either on the day preceding the announcement (as in the UK, Hong Kong, Canada and Australia), a week after the repurchase (as in France) or at the end of the quarter (as in the USA). In the USA there was no formal requirement to announce share repurchases prior to 2004. However, since 2004 companies need to announce share repurchases on a quarterly basis (disclosing figures for each month). Prior to 2004 USA companies usually only announced their intention to repurchase in the financial press. (Kobokoane, 2007: 16, 17; Mitchell \& Dharmawan, 2007: 149; Ginglinger \& Hamon, 2007: 919).

\section{Share repurchase trends}

South African share repurchases got off to a slow start owing to uncertainty regarding the treatment of repurchases under tax laws at the time, as well as inconsistency between the Companies Act and the JSE Listing Requirements. Once the tax implications had been clarified and companies became familiar with this new distribution mechanism, repurchase programmes were initiated by many listed companies (Daly, 2002: 47). The first repurchase announcement was made by Quyn Holdings on 17 December 1999 (Bester, 2008: 96). By the end of the third quarter of 2001, 45 different companies had made 88 open market repurchase announcements via SENS. These share repurchases were mainly conducted in the retail, financial services, and information technology sectors, and their total value was R6,3 billion, representing an average of $8,01 \%$ of their issued share capital (Daly, 2002: 49, 69). Bhana (2007) reported that during the period October 2000 and March 2003, 117 open market repurchase announcements were made. In a recent study by Bester (2008), it was found that 121 JSE-listed companies had made 312 repurchase announcements over the period from July 1999 to June 2007. The total number of repurchased shares noted in the 312 announcements was 4,2 billion shares worth a total value of R47,2 billion (Bester, 2008: 94). Chivaka, Siddle, Bayne, Cairney and Shev (2009) examined a total of 55 specific repurchase announcements (by 47 companies) in the time period 1999 to the end of 2004 to establish the reasons for repurchases that were stated by directors in the SENS circulars.

Research on South African share repurchase activities has thus far been based predominantly on announced general repurchases. This category of share repurchases may however not represent the full extent of share repurchases in South Africa. Regulations on open market repurchases are more flexible and less cumbersome than specific repurchases and it is expected that companies would show a 
preference for open market repurchases over fixed price share repurchases. The practice of announcing general (or open market) repurchases only as they exceed cumulative $3 \%$ increments of issued shares may result in significant understatement of actual general share repurchase activities.

Furthermore, the fact that the shares of South African holding companies may be repurchased by their subsidiaries (or share trusts) complicates the assessment of share buyback activities. These shares (also known as treasury shares) may subsequently be sold back to the holding company (and then cancelled by the holding company) or to other entities within the group or to entities not within the group. South African research should therefore incorporate the effect of treasury shares on share repurchase activities.

\section{Data collection}

Three sets of data are required to evaluate the trends in repurchase activities, as discussed in the previous section. In the first place, detailed information regarding share repurchase announcements is required. Secondly, all actual repurchases are required in order to determine the split between announced general repurchases and unannounced general repurchases; actual general repurchases and actual specific repurchases; and actual unannounced and announced total repurchases. Thirdly, detailed information on the repurchasing entity is required to quantify actual share repurchases (and sales) conducted by the subsidiaries (and share trusts).

Data collection in South Africa was given a jump-start by empirical repurchase data collected by Daly (2002). Daly analysed the share returns of 45 JSE-listed companies that made 88 announcements of share repurchases under a general authority between 1 July 1999 and 30 September 2001. Details of repurchase transactions included names of companies, dates of SENS announcements and values of the repurchases, as well as whether the repurchases were made by the company or the subsidiary. Daly's report could therefore be used as a basis for data collection. Bhana (2007) published the first scientific article on this topic in South Africa. His research covered the period October 2000 to March 2003 with a sample comprising 117 repurchase announcements. Unfortunately this sample was not listed in the article and the data could therefore not be used to expand Daly's dataset. Furthermore, Daly's research sample comprised the 3\% SENS announcements of actual general share repurchases (Daly, 2002: 39), whereas Bhana's research sample consisted of general repurchase announcements of intention to repurchase, irrespective of whether the repurchases were actually executed (Bhana, 2007: 27). Announcements of intentions to repurchase via general authority hold little resemblance to actual repurchases, owing to the fact that a general offer does not constitute a binding commitment. It has become common practice for companies to obtain authorisation for general share repurchases during annual shareholders' meetings, irrespective of whether they have specific intentions to repurchase shares.

Bester (2008) verified and expanded Daly's dataset to include 121 JSE-listed companies making 312 repurchase announcements over the period from July 1999 to June 2007. Specific repurchase details (including names of companies, number of SENS announcements and values of the repurchases) were published in the research report by Bester. These announcements include general and specific repurchases, but do not consistently include announcements about repurchases by the company from its own subsidiaries and exclude share trusts. A comprehensive database of actual share repurchase activities by all JSE-listed companies was not compiled by Bester. Chivaka et al. (2009) examined the SENS announcements of 55 specific repurchases announcements over the period 1999 until the end of 2004. Unfortunately no details of the repurchase transactions that were selected were included in the research report of Chivaka et al. (2009).

Different approaches can be used to expand the dataset on South African share buy-backs. In this study the first approach was to search SENS or news announcements of companies' repurchase activities. This is a quick way of obtaining repurchase data, because the information can be obtained via electronic searches of the JSE SENS announcements as stored in McGregor BFA news service. Since the format of the SENS announcements has been inconsistent over time, the following keywords were used, one by one, to identify the required announcements: "repurchase", "buy-back", "buy back", "buyback" and "treasury".

Information regarding specific repurchases sourced in this manner is quite reliable because these offers usually result in actual repurchases when accepted by shareholders. However, the incremental 3\% SENS announcements in respect of actual share buy-backs under general authority have an obvious limitation, because some companies may have carried out share repurchases over a specific period, but failed to cross the $3 \%$ threshold and therefore no announcement in that specific period is made. This data collection approach therefore does not uncover the complete extent of general share repurchases in South Africa over a specific time period. It also does not uncover accurate data regarding movement of shares between repurchase entities (i.e. holding company, subsidiaries and share trust).

A significantly more labour-intensive approach was adopted to determine the actual shares repurchased by analysing the annual reports from 1999 to 2008 and noting changes in the number of shares issued. The directors' reports, share capital notes to the balance sheet and shareholder analysis (or shareholder spread) of annual reports were scanned carefully for changes in issued shares, including treasury shares held by subsidiaries or share trusts. Although this approach proved to be immensely time-consuming, the authors were able to identify repurchases by the company (that were cancelled), repurchases and sales by subsidiaries (and not cancelled but regarded as treasury shares and consolidated), as well as details of consolidated share trusts.

Finally, an extensive verification process was followed to ensure that no repurchase activities had been omitted. This process was based on comparing the total share repurchases (as obtained from the annual reports) with the announced share repurchases (as derived from the SENS 
announcements) to obtain the unannounced general share repurchases.

\section{Sample selection}

Since none of the financial data sources like Reuters, McGregor BFA or I-Net Bridge has kept detailed records on share repurchase activities for the nine years (1999-2008) and given the difficulties encountered in compiling a repurchase database, the authors decided to select a small sample of JSE-listed companies on which to base their research. The sample of 33 companies was selected so as to include a balanced proportion of Top 40, Mid Cap, and Small Cap stocks. The names of the 33 companies are given in Table 1. The selection of the 33 companies was based on the following principles:

- The company entered into repurchase activities in respect of listed ordinary or listed $\mathrm{N}$-shares during the period 1 July 1999 until its 2008 financial year-end;

- Where only share trust consolidations occurred, the company was excluded from the sample;

- $\quad$ All odd lot offers were excluded because odd lot offers have existed prior to 1 July 1999;

- The company is a Top 40, Mid Cap or Small Cap company.

\section{Research methodology}

The share repurchase data captured reflect actual annual repurchases (based on annual reports) and repurchases announced via SENS respectively. In the split between repurchasing entities, a distinction is made between shares repurchased by the company from shareholders (other than subsidiaries and share trusts), shares repurchased by the subsidiaries, treasury shares sold by the subsidiary to the company, treasury shares sold by the subsidiary to parties other than entities in the group, as well as the net movement of shares repurchased or sold by the share trusts. In the split between the two repurchase methods, general or specific, the specific repurchases are further split into share repurchases by the company of its shares previously held by the subsidiary, pro rata share repurchases and other specific repurchases (i.e. specific offers).

Both volume (i.e. number of shares) and value (i.e. rand) splits are calculated in respect of all the data, except in the split between reporting entities where share trusts are only expressed as the annual net number of treasury shares.

The data collected in respect of the 33 companies were compared to achieve the aim of the study, namely:

1. The announcements of actual general and specific share buy-backs were compared to the actual share repurchases to obtain the unannounced general repurchases and to quantify the split between total announced and unannounced repurchases.
2. Actual general and specific share buy-backs were compared to ascertain the split between specific and general repurchases.

3. Repurchasing entities were compared to confirm which portion of share repurchases is affected by the different repurchasing entities (i.e. the company, subsidiary and share trust).

The share repurchase trends observed in each of these three comparisons will be expressed as percentages to reflect the split in both number of shares repurchased as well as in rand value.

Although the necessary care was taken to ensure that all data were accurately reflected in the databases, the following problems were encountered:

- The annual movement in the number of treasury shares is hardly ever disclosed separately by reporting entities. The movement in treasury shares held by subsidiaries could be recalculated fairly accurately by scrutinising the directors' report, share capital note and the shareholder spread. However, the movement in treasury shares held by share trusts could not be split between repurchases from the company and the subsequent sale thereof (either to beneficiaries or to the holding company) as annual reports generally do not provide a separate note or additional information regarding the annual movement in shares held by the share trust. The only workable option was to compare the opening and closing balance of the shares held by the share trust (as disclosed in the annual reports) and to recalculate a net annual movement.

Furthermore, it may not be entirely obvious from annual reports whether a company has control over its share trusts and whether the trusts need to be consolidated. If share trust consolidation is not mentioned explicitly in the annual report, it is assumed that the company (and hence its auditors) does not require share trust consolidation.

- The rand value of treasury shares sold by the subsidiary to the company is seldom reported separately in the consolidated annual report (as it has a nil net effect on consolidation). Rand amounts could only be obtained if the repurchase thereof by the company was announced via SENS or if it could be recalculated as the difference between the repurchase amount included in the group statement of changes in equity and the company statement of changes in equity.

- The rand value of treasury shares sold by the subsidiary to entities not within the group is seldom reported separately in the annual report. Rand amounts could only be obtained if they could be recalculated as the difference between the repurchase amount disclosed (either via SENS or in another section of the annual report) and the net amount included in respect of treasury shares in the statement of changes in equity. 
- The rand value relating to the net movement in treasury shares held by the share trusts could not be calculated as it is seldom reported separately in the annual report and no SENS announcement is required in respect of share trust repurchases.

- The rand values of announced repurchases always reflect the amount reported via SENS. For unannounced repurchases (and sales), the rand values represent a balancing figure obtained from the figure included in the statement of changes in equity in the annual report. The amount reported via SENS however does not consistently include costs, whereas the amount reflected in the statement of changes in equity includes all costs.

Total share repurchase activity for the purpose of this study comprises own shares purchased by the company (from shareholders other than entities within the group), treasury shares purchased by subsidiaries and treasury shares (previously held by subsidiaries) subsequently purchased by the holding company. Since share trust repurchases are not treated as share repurchases in the Companies Act and the Listing Requirements, the authors deemed it fit to exclude the net movement in shares held by the share incentive trusts from share repurchase activities. The net movement in shares held by the share incentive trusts will however be discussed in the results section.

The number of shares repurchased best reflects the level of share repurchase activity. While value repurchased is a good indication of method or entity split in a specified period, it is not a suitable measure of changes in the repurchase level over time, because of the artificial influence of share price fluctuations. Also, owing to the problems encountered in ascertaining the value of certain repurchases (as discussed above under problems encountered), the value included in the database does not in all instances fully reflect comprehensive values.

\section{Results}

This study finds that 33 companies made 71 repurchase announcements via SENS over the period from July 1999 until their financial year ending in 2008. Table 1 shows that these announcements include 47 general and 24 specific announcements about repurchases by the company from its shareholders, including its own subsidiaries but excluding share trusts. Astrapak Ltd and Massmart Holdings Ltd made no announcements via SENS, but undertook unannounced repurchasing activities during the target period.

Table 2 shows that the total number of actual shares repurchased under general authority by the 33 companies over the period from July 1999 until their financial year ending in 2008 was 1,104 billion shares (worth a total value of R31,544 billion). Only $41,0 \%$ of the number of shares repurchased under general authority was noted in the $3 \%$ SENS announcements of the 33 companies. (In value, the announced general repurchases represents $50,7 \%$ of the actual share repurchases under general authority.)

Table 3 shows that a total number of 2,306 billion shares (to the value of R52,133 billion) was actually repurchased by the 33 companies during the target period. $52,1 \%$ of these shares were repurchased under specific authority in terms of volume (and only $39,5 \%$ in terms of value).

The split by entity in Table 4 is based on a total number of actual shares (including share trust consolidations) of 2,707 billion that was repurchased by the 33 companies during the target period. Of these shares, $22,3 \%$ were initially repurchased by the company, $48,4 \%$ by subsidiaries. The company subsequently repurchased $14,5 \%$ from the subsidiaries and $14,8 \%$ represents share trust consolidations. When excluding share trust consolidations from the share repurchase activities, share repurchases of 2,306 billion shares were affected as follows by the repurchasing entities: $26,1 \%$ were initially repurchased by the company; $56,8 \%$ by subsidiaries and $17,1 \%$ represented shares subsequently repurchased by the company from the subsidiaries. (These repurchases represented an amount of R52,133 billion which was affected as follows by the repurchasing entities: $29,1 \%$, $53,7 \%$ and $17,2 \%$ respectively.)

Table 5 reveals that of the total share repurchases of 2,306 billion shares, $69,1 \%$ were announced and $30,9 \%$ were unannounced. (In terms of value the announced repurchases amount to $69,8 \%$ and the unannounced repurchases to $30,2 \%$.) All the unannounced specific repurchases comprise shares subsequently repurchased by the company from the subsidiary. In the sample of 33 companies, there were 16 of these repurchases (by the company from the subsidiary) of which only 8 were announced via SENS. 
Table 1: Companies included in pilot study

\begin{tabular}{|c|c|c|c|c|}
\hline \multirow[b]{2}{*}{ No. } & \multirow[b]{2}{*}{ Company name } & \multicolumn{3}{|c|}{ Announcements } \\
\hline & & $\begin{array}{c}\text { Number of } \\
\text { announcements }\end{array}$ & $\begin{array}{l}\text { General } \\
\text { authority }\end{array}$ & $\begin{array}{l}\text { Specific } \\
\text { authority }\end{array}$ \\
\hline 1 & AECI Ltd & 1 & 0 & 1 \\
\hline 2 & Afgri Ltd & 2 & 2 & 0 \\
\hline 3 & African Oxygen Ltd & 1 & 0 & 1 \\
\hline 4 & Astral Foods Ltd & 3 & 3 & 0 \\
\hline 5 & Astrapak Ltd & 0 & 0 & 0 \\
\hline 6 & Aveng Ltd & 2 & 1 & 1 \\
\hline 7 & AVI Ltd & 2 & 1 & 1 \\
\hline 8 & Barloworld Ltd & 4 & 3 & 1 \\
\hline 9 & Brandcorp Holdings Ltd & 6 & 5 & 1 \\
\hline 10 & Control Instruments Group Ltd & 1 & 0 & 1 \\
\hline 11 & Edgars Consolidated Stores Ltd & 4 & 4 & 0 \\
\hline 12 & ERP.com Holdings Ltd & 1 & 1 & 0 \\
\hline 13 & Faritec Holdings Ltd & 2 & 2 & 0 \\
\hline 14 & Gold Reef Resorts Ltd & 1 & 0 & 1 \\
\hline 15 & Imperial Holdings Ltd & 2 & 2 & 0 \\
\hline 16 & Lewis Group Ltd & 3 & 3 & 0 \\
\hline 17 & Massmart Holdings Ltd & 0 & 0 & 0 \\
\hline 18 & Murray \& Roberts Holdings Ltd & 1 & 0 & 1 \\
\hline 19 & Nampak Ltd & 1 & 0 & 1 \\
\hline 20 & Netcare Ltd & 3 & 0 & 3 \\
\hline 21 & OneLoqix Group Ltd & 2 & 0 & 2 \\
\hline 22 & Remgro Ltd & 2 & 1 & 1 \\
\hline 23 & Reunert Ltd & 3 & 2 & 1 \\
\hline 24 & Set Point Technology Holdings Ltd & 1 & 0 & 1 \\
\hline 25 & Shoprite Holdings Ltd & 1 & 0 & 1 \\
\hline 26 & Spur Corporation Ltd & 2 & 1 & 1 \\
\hline 27 & Sun International Ltd & 2 & 1 & 1 \\
\hline 28 & Telkom SA Ltd & 3 & 3 & 0 \\
\hline 29 & The Bidvest Group Ltd & 2 & 1 & 1 \\
\hline 30 & The House of Busby Ltd & 5 & 5 & 0 \\
\hline 31 & Tiger Brands Ltd & 1 & 1 & 0 \\
\hline 32 & Truworths International Ltd & 4 & 3 & 1 \\
\hline \multirow[t]{2}{*}{33} & Woolworths Holdings Ltd & 3 & 2 & 1 \\
\hline & Total & 71 & 47 & 24 \\
\hline
\end{tabular}


Table 2: Share buy-backs under general authority

\begin{tabular}{|c|c|c|c|c|}
\hline & Number & $\%$ & Rand & $\%$ \\
\hline Announced buy-backs & 452548395 & 41,0 & 15988962879 & 50,7 \\
\hline Unannounced buy-backs & 651437459 & 59,0 & 15554741460 & 49,3 \\
\hline \multicolumn{5}{|c|}{ Total buy-backs under general authority } \\
\hline & 1103985854 & 100,0 & 31543704339 & 100,0 \\
\hline
\end{tabular}

Table 3: Share buy-backs: specific vs. general authority

\begin{tabular}{|c|c|c|c|c|}
\hline & Number & $\%$ & Rand & $\%$ \\
\hline Buy-backs under specific authority & 1202207701 & 52,1 & 20589464947 & 39,5 \\
\hline $\begin{array}{l}\text { Treasury shares purchased } \\
\text { from subsidiary }\end{array}$ & 393999684 & & 8982718031 & \\
\hline Other & 483042682 & & 5405386110 & \\
\hline Pro rata offer & 325165335 & & 6201360806 & \\
\hline Buy-backs under general authority & 1103985854 & 47,9 & 31543704339 & 60,5 \\
\hline Total share buy-backs & 2306193555 & 100,0 & 52133169286 & 100,0 \\
\hline
\end{tabular}

In Table 6 it is revealed that the total number of 2,306 billion shares repurchased by the sample companies during the target period does not reflect the fact that 394 million shares were subsequently sold by the subsidiaries to their holding companies and 86,5 million shares were sold by the subsidiaries to parties not within the group. Of the initial share repurchases, $20,8 \%$ were therefore subsequently sold in terms of volume (and 21,3\% in terms of value).
The actual share repurchase activities of the 33 companies over the target period were 2,306 billion shares (representing R52,133 billion in value). As seen in Table 7, share repurchases got off to a belated start in $2000(3,4 \%)$, increased in $2001(11,1 \%)$, peaked at $12,8 \%$ in 2002 and then slowed down again in 2003 to $2004(9,0 \%$ in 2003 and $9,6 \%$ in 2004). They increased in 2005 (16,1\%), while 2006 represents the year with the highest share repurchase activity $(27,6 \%)$ during the target period, with a dramatic drop in $2007(4,2 \%)$ and 2008 marginally higher than 2007, at 6,2\%.

Table 4: Share buy-backs by repurchasing entity

\begin{tabular}{|c|c|c|c|c|c|}
\hline & Number & $\%$ & $\%$ & Rand & $\%$ \\
\hline \multicolumn{6}{|c|}{ Company own shares repurchased } \\
\hline & 602942440 & 22,3 & 26,1 & 15141708866 & 29,1 \\
\hline Subsidiary purchases & 1309251431 & 48,4 & 56,8 & 28008742389 & 53,7 \\
\hline Subtotal & 1912193871 & 70,7 & 82,9 & 43150451255 & 82,8 \\
\hline $\begin{array}{l}\text { Company repurchases sha } \\
\text { subsidiary }\end{array}$ & 393999684 & 14,5 & 17,1 & 8982718031 & 17,2 \\
\hline $\begin{array}{l}\text { Share buy-backs excludin } \\
\text { consolidations }\end{array}$ & 2306193555 & 85,2 & 100,0 & 52133169286 & 100,0 \\
\hline Share trusts consolidated & 400995795 & 14,8 & & & \\
\hline Total share buy-backs & 2707189350 & 100,0 & & & \\
\hline
\end{tabular}


Table 5: Share buy-backs: announced vs. unannounced

\begin{tabular}{|c|c|c|c|c|}
\hline & Number & $\%$ & Rand & $\%$ \\
\hline Buy-backs under specific authority & 1202207701 & & 20589464947 & \\
\hline Announced & 1142142172 & & 20385659947 & \\
\hline Unannounced & 60065529 & & 203805000 & \\
\hline Buy-backs under general authority & 1103985854 & & 31543704339 & \\
\hline Announced & 452548395 & & 15988962879 & \\
\hline Unannounced & 651437459 & & 15554741460 & \\
\hline Total share buy-backs & 2306193555 & 100,0 & 52133169286 & 100,0 \\
\hline Announced & 1594690567 & 69,1 & 36374622826 & 69,8 \\
\hline Unannounced & 711502988 & 30,9 & 15758546460 & 30,2 \\
\hline
\end{tabular}

Table 6: Share buy-backs: purchases and sales

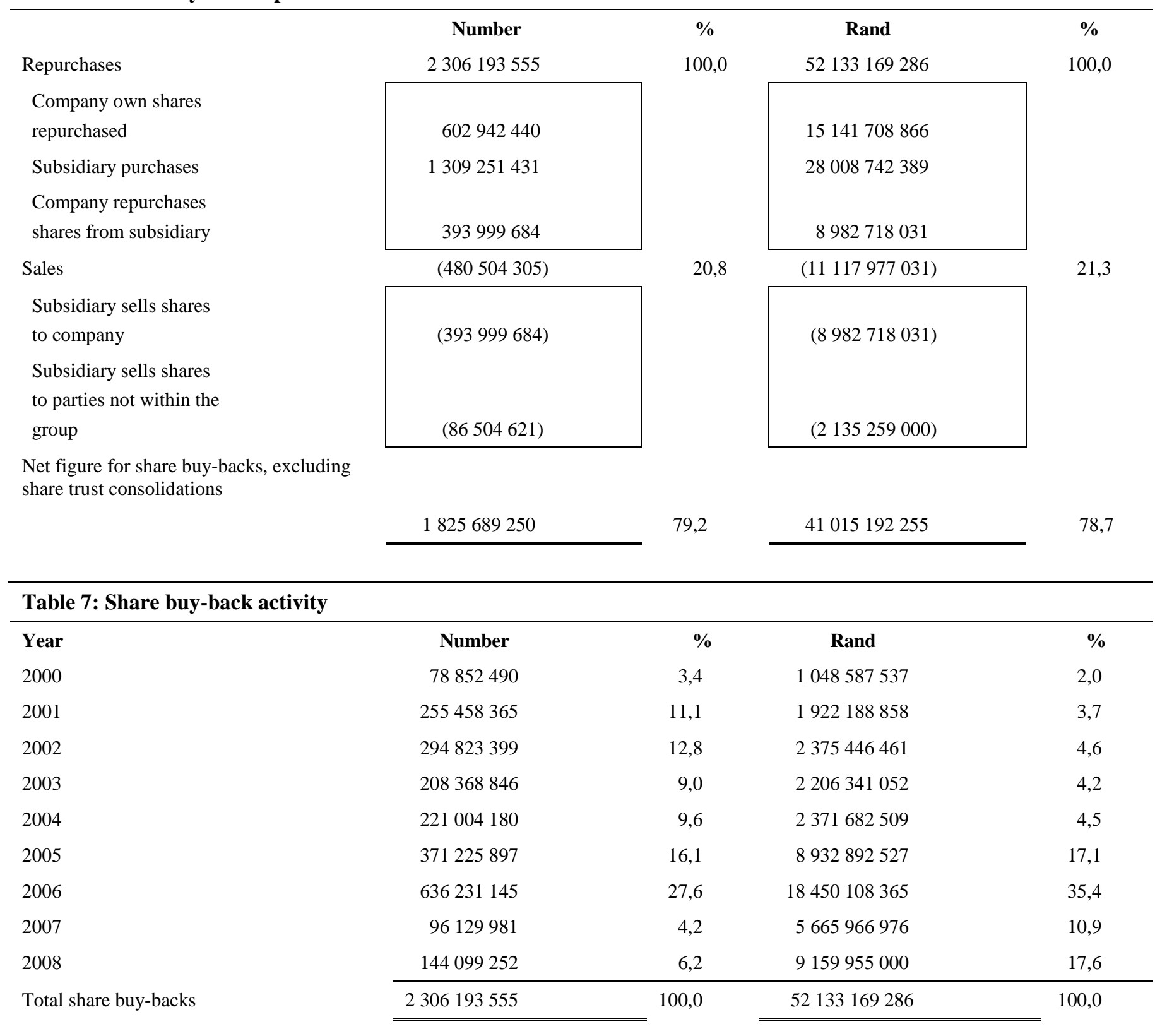




\section{Problems identified in respect of research on share repurchase activities}

The details on share buy-backs by JSE-listed companies are presently not well reported. The following problems were experienced in obtaining information on share repurchases during this research:

- None of the financial data sources like Reuters, McGregor BFA or I-Net Bridge keep detailed records on share repurchase activities for the nine years (19992008). Research or analysis on share buy-backs therefore requires time-consuming investigation of the SENS database and company annual reports. Even the database search on SENS proved to be inaccurate owing to inconsistent use of terminology. For example share repurchase announcements could include any of the following key words or phrases: "repurchase", "buy-back", "buy back", "buyback", "treasury", etc.

- Actual share repurchases under general authority are only reported on SENS at each 3\% increment, which means that if general repurchases remain below this limit, they may not be reported in SENS. Share repurchases are normally mentioned in the annual report under the chairman's review or the directors' report. However, these references do not always provide detailed information in terms of the number of shares repurchased, purchasing entity, and the cost of the repurchase. Ultimately a detailed review of the notes on financial statements is required to determine accurate share repurchase activities.

- Company annual reports do not always show an annual reconciliation of treasury shares (neither in number nor rand) and seldom distinguish between treasury shares held by subsidiaries and share trusts in the notes to the financial statements. Treasury shares repurchased (and sold) by subsidiaries could therefore only be split between number and value by scrutinising other sections of the financial statements (i.e. the directors' report, statement of changes in equity and the shareholder spread section) in combination with SENS announcements (if applicable). Share trust repurchase activity could however not be split between repurchases and sales (only a net annual movement in number could be calculated), as there is inadequate reporting thereof in annual reports and because share trust repurchases are not reported via SENS.

The following recommendations are put forward to improve analysis and research on share repurchases activities of JSElisted companies:

- $\quad$ SENS announcement should be standardised in terms of terminology to enable accurate data searches. This could be achieved through SENS announcement templates with predefined titles or SENS identification codes that identify particular types of announcements. It is worth noting that companies listed on the London Stock Exchange or Alternative Index Market, like BHP Billiton and SABMiller, announce repurchases on a daily basis as they are transacted. This allows analysts to keep better track of repurchase activities and consistently discount the value of the repurchases. It is recommend that JSE share repurchases should also be announced on a daily basis.

- A share repurchase summary should be included in annual reports in the directors' report under the share capital topic with specific reference to number of shares repurchased, value/cost of repurchases, and repurchasing entity (i.e. company, subsidiary or share incentive trust).

\section{Summary and conclusion}

This study was performed on share repurchase activities of 33 JSE-listed companies over nine years, from July 1999 till their financial year ending in 2008. The study concentrated on the methods applied in previous studies conducted in South Africa. Daly (2002) analysed the share returns of 45 JSE-listed companies that made 88 announcements of actual share repurchases under a general authority between 1 July 1999 and 30 September 2001. Bhana (2007) covered the period October 2000 to March 2003 and his sample comprised 117 announcements of intention to repurchase under general authority.

Owing to the peculiar South African regulation in respect of general (open market) repurchases, namely having to announce only incremental repurchases of $3 \%$ or more via SENS, it is expected that the announced general repurchases may understate the total actual general repurchases. A comparison of actual repurchases under a general authority (as published in annual reports) with general repurchases announced via SENS does in fact reveal that on average $59,0 \%$ of the total number of shares (and $49,3 \%$ of the total value) repurchased under a general authority is not included in the $3 \%$ SENS announcements.

Share repurchases are expected to be predominantly executed as general repurchases (as opposed to specific repurchases), owing to the more flexible nature of the requirements relating to general repurchases. This study however shows that general share repurchases represent $47,9 \%$ of total repurchases in volume (and $60,5 \%$ in terms of value). Omission of specific repurchases in share repurchase studies will therefore lead to a material understatement of share repurchase activities.

In South Africa, subsidiaries may repurchase the holding company's shares (up to $10 \%$ in total) and share trusts may hold company shares. Other countries however usually only allow share repurchases of own shares by the holding company and disallow share repurchases of the holding company's shares by subsidiaries (and share trusts). This study shows that total share repurchases (excluding share trust purchases) are affected in number by the different repurchasing entities as follows: $26,1 \%$ by the company (excluding subsequent repurchases of subsidiary treasury shares); $56,8 \%$ by the subsidiary and $17,1 \%$ in respect of the subsequent repurchases of subsidiary treasury shares by the company. (In value these repurchases represent 29,1\%, $53,7 \%$ and $17,2 \%$, respectively.) The effect of subsidiary share repurchases, as well as the re-acquisition by the 
holding company of shares previously held by the subsidiary, needs to be acknowledged in South African buyand-hold studies and presents unique challenges.

This study found that subsequent specific repurchases of subsidiary treasury shares by the company are not always reported via SENS. These unannounced specific repurchases, as well as the general repurchases under the $3 \%$ SENS limit, lead to approximately $30,9 \%$ of the total number of shares repurchased (and $30,2 \%$ in value) not being announced through SENS. Buy-and-hold simulations on unannounced share repurchases are problematic as there is no repurchase date available from the existing data sources.

This investigation of share repurchase trends has revealed several problems in the collection of accurate information on share repurchase activities. In the first place, no existing database of share repurchase information exists at present, so all data had to be collected from their initial source. Secondly, share repurchase announcements of general repurchases understate actual repurchases by a significant proportion and annual reports therefore needed to be consulted as well. Finally, treasury shares held by subsidiaries (and share trusts) are not consistently reported in company annual reports, thus requiring a time-consuming analysis of each entire annual report. It is recommended that certain changes be considered to improve overall reporting of share repurchase activities. These may include announcing actual share repurchases by the JSE on a daily basis (rather than waiting for each $3 \%$ increment in respect of general repurchases), standardising the format of announcements made via SENS, and instituting accounting guidelines to govern the reporting of share repurchases in annual reports.

While this study of 33 companies during the target period may not be entirely accurate owing to the relatively small data sample, there is a clear indication that research based only on $3 \%$ announcements of general share buy-backs results in significant understating of actual total share buyback activities and that the South African share repurchase environment presents unique challenges. The share repurchase activity over a recent period of nine years (1999 - 2008) also reveals that share repurchases are still carried out extensively by JSE-listed companies. The lack of a comprehensive database of detailed share repurchase activities will remain a key obstacle in pursuit of ongoing research on this subject.

Future studies will research the efficiency/inefficiency of share repurchases (including buy-and-hold simulation), as well as the economic reasons for share repurchases (including, among others, net asset value per share compared to share price to establish over- and under-priced companies).

\section{References}

Banyi, M.L., Dyl, E.A. \& Kahle, K.M. 2008. 'Errors in estimating share repurchases', Journal of Corporate Finance, 14(4): 460-474.
Bester, P.G. 2008. 'Shareholder distribution choices for industrial companies listed on the JSE: Share buybacks vs. dividends'. Unpublished MBA research report. Bellville: University of Stellenbosch.

Bhana, D. 2006. 'The company law implications of conferring a power on a subsidiary to acquire the shares of its holding company', Stellenbosch Law Review, 17(2): 232250 .

Bhana, N. 2007. 'The market reaction to open market share repurchases announcement: The South African experience', Investment Analysts Journal, 65: 25-36.

Cassim, F.H.I. 2003. 'The repurchase by a company of its own shares: The concept of treasury shares', Stellenbosch Law Review, 120(1): 137-152.

Chivaka, R., Siddle, A., Bayne, L., Cairney, C. \& Shev, J. 2009. 'Reasons for share repurchases in South Africa: Theory versus practice', SA Journal of Accounting Research, 23(1): 1-30.

Daly, K.J. 2002. 'Share returns of companies announcing share repurchases under a general authority'. Unpublished MBA research report. Johannesburg: University of the Witwatersrand.

Fairchild, R. \& Zhang, G. 2005. Repurchase and dividend catering, managerial myopia, and long-run value destructions. Working paper series 2005-21. Bath: University of Bath School of Management.

Ginglinger, E. \& Hamon, J. 2007. 'Actual share repurchases, timing and liquidity', Journal of Banking \& Finance, 31(3): 915-938.

Grullon, G. \& Michaely, R. 2002. 'Dividends, share repurchases, and the substitution hypothesis', Journal of Finance, 57(4): 1 649-1 684.

Ikenberry, D., Lakonishok, J. \& Vermaelen, T. 1995. 'Market underreaction to open market share repurchases', Journal of Financial Economics, 39: 181-208.

JSE. 2007. 'JSE Listing requirements'. Service Issue no 3. Johannesburg. LexisNexis Butterworths. [online] URL: http://www.jse.co.za/listing_requirements.jsp. Accessed 10 April 2008.

Kobokoane, N. 2007. 'Share buybacks in South Africa: an empirical investigation'. Unpublished MBA research report. Bellville: University of Stellenbosch.

Mitchell, J.D. \& Dharmawan, G.V. 2007. 'Incentives for market buy-backs: Evidence from a transparent buy-back regime', Journal of Corporate Finance, 13(1): 146-169.

RSA (Republic of South Africa). The Companies Act, no. 61 of 1973. Pretoria: Government Printer. 
RSA (Republic of South Africa). The Companies Amendment Act, no. 37 of 1999. Pretoria: Government Printer.

SAICA (South African Institute of Chartered Accountants). GAAP Monitoring Panel. 2004. 'Treatment of company share trusts in consolidated group financial statements'. [online] URL:

https://www.saica.co.za/documents/TREATMENT_SHARE TRUST_FS.pdf. Accessed 10 April 2008.

SAICA (South African Institute of Chartered Accountants). 2007a. 'Consolidated and separate financial statements'. IAS 27 (AC 132). Updated January. Pietermaritzburg: Interpak Books.

SAICA (South African Institute of Chartered Accountants). 2007b. 'Financial instruments: Presentation'. IAS 32 (AC 125). Updated: January. Pietermaritzburg: Interpak Books.

Wainer, H. 2004. 'Consolidation of share incentive trusts touching a nerve', Accountancy SA, July: 12-13. 